DOI: $\underline{\text { https://doi.org/10.24127/ajpm.v10i4.4250 }}$

\title{
PENGEMBANGAN MODUL MATEMATIKA DENGAN PENDEKATAN SAINTIFIK UNTUK MENINGKATKAN KEMAMPUAN PEMECAHAN MASALAH MATEMATIKA
}

\author{
Mila Karmila Sidik ${ }^{1}$, Luthfi Rumbia ${ }^{2}$ \\ ${ }^{1}$ Pendidikan Matematika, STKIP Gotong Royong Masohi \\ ${ }^{2}$ Pendidikan Biologi, STKIP Gotong Royong Masohi \\ *Corresponding author. \\ E-mail: milasidik19@ gmail.com ${ }^{1)}$ \\ rumbialuthfi@gmail.com 2)
}

Received 17 September 2021; Received in revised form 17 November 2021; Accepted 28 December 2021

\begin{abstract}
Abstrak
Tujuan penelitian ini adalah menghasilkan modul pembelajaran matematika dengan pendekatan saintifik untuk meningkatkan kemampuan pemecahan masalah matematika siswa yang valid, praktis dan efektif. Dalam penelitian pengembangan ini mengacu pada model pengembangan ADDIE. Pengembangan dilakukan melalui analisis, desain, pengembangan, implementasi dan evaluasi. Hasil penelitian menunjukkan Kevalidan berdasarkan validasi materi, desain dan Bahasa. Diperoleh nilai validasi materi yaitu 96, nilai validasi desain yaitu 100 dan nilai validasi Bahasa yaitu 96. Sehingga modul pembelajaran matematika adalah "sangat valid" dan sudah layak digunakan. Kepraktisan dinilai oleh guru matematika dan siswa kelas V MIS Al-Hilaal Laimu Kecamatan Tehoru. Diperoleh skor penilaian guru yaitu 96 dan penilaian siswa yaitu 70. Sehingga untuk kepraktisan modul pembelajaran matematika adalah "sangat praktis" dan sudah layak digunakan. Keefektifan dilihat dari meningkatnya hasil kemampuan pemecahan masalah matematika siswa yang berada pada kategori sedang dan tinggi sehingga keefektifan modul pembelajaran matematika yang telah dibuat "sangat efektif". Disimpulkan ketiga indikator yaitu kevalidan, kepraktisan dan keefektifan pada modul pembelajaran matematika memiliki kelayakan baik dan dapat digunakan dalam pembelajaran.
\end{abstract}

Kata kunci: Modul matematika; pemecahan masalah; saintifik.

\begin{abstract}
The purpose of this research is to produce a mathematical learning module with a scientific approach to improve students' mathematical problem solving skills that are valid, practical and effective. In this development research refers to the ADDIE development model. Development is carried out through analysis, design, development, implementation and evaluation. The results showed that the validity was based on the validation of the material, design and language. The material validation value obtained is 96, the design validation value is 100 and the language validation value is 96. So the mathematics learning module is "very valid" and is feasible to use. Practicality was assessed by mathematics teachers and fifth grade students at MIS Al-Hilaal Laimu, Tehoru District. The teacher's assessment score is 96 and the student's assessment is 70. So that the practicality of the mathematics learning module is "very practical" and is feasible to use. The effectiveness is seen from the increase in the results of students' mathematical problem solving abilities who are in the medium and high categories so that the effectiveness of the mathematics learning module that has been made is "very effective". It is concluded that the three indicators, namely the validity, practicality and effectiveness of the mathematics learning module have good feasibility and can be used in learning.
\end{abstract}

Keywords: Mathematics module; problem solving; scientific.

This is an open access article under the Creative Commons Attribution 4.0 International License 
DOI: https://doi.org/10.24127/ajpm.v10i4.4250

\section{PENDAHULUAN}

Masalah dalam matematika merupakan sebuah tantangan apabila penyeleseaian memerlukan kreativitas, pengertian dan pemikiran. Menurut Hidayati \& Widodo (2015), terdapat dua hal terkait masalah matematika: 1) suatu pertanyaan akan menjadi masalah jika pertanyaan itu menunjukkan adanya suatu tantangan yang tidak dapat dipecahkan dengan suatu prosedur yang sudah diketahui oleh penjawab pertanyaan, 2) suatu masalah bagi siswa A belum tentu menjadi masalah bagi siswa B jika siswa B sudah mengetahui prosedur untuk menyelesaikannya. Menurut Ahmad \& Asmaidah (2017), kemampuan pemecahan masalah yang dimiliki akan semakin meningkat apabila melakukan kegiatan pemecahan masalah terhadap masalah-masalah yang baru.

Melatih siswa dengan pemecahan masalah dalam pembelajaran matematika bukan hanya sekedar mengharapkan siswa dapat menyelesaikan soal atau masalah yang diberikan, namun diharapkan kebiasaaan dalam melakukan proses pemecahan masalah membuatnya mampu menjalani hidup yang penuh kompleksitas permasalahan (Harahap \& Surya, 2017). Siswa dikatakan mampu memecahkan masalah matematika jika siswa dapat memahami, memilih strategi yang tepat kemudian menerapkannya dalam penyelesaian masalah (Latifah \& Afriansyah, 2021).

Menurut Sidik (2017), pemecahan masalah adalah cara berpikir yang melibatkan banyak pengetahuan untuk mencari jalan keluar dari suatu kesulitan atau permasalahan untuk mencapai tujuan akhir. Pemecahan masalah merupakan bagian penting dalam pembelajaran matematika (Laila \& Darmawan, 2021). Sehingga guru memiliki peranan penting dalam menyiapkan sumber belajar berupa modul matematika yang menjadi pegangan guru dalam kegiatan belajar mengajar di kelas.

Penggunaan modul dalam kegiatan belajar mengajar tidak hanya memandang aktivitas guru semata, melainkan juga melibatkan siswa secara aktif dalam belajar (Sukiminiandari, Budi, \& Supriyati, 2015). Selan itu, proses pembelajaran dengan menggunakan modul, siswa dituntut untuk belajar mandiri dan mampu memecahkan masalah dengan memberikan ide-ide yang baru (Anggoro, 2015). Hal ini dikarenakan guru berperan membagikan dan mengarahkan modul kepada siswa, sehingga guru dapat melihat seberapa jauh siswa mampu dalam memecahkan masalah.

Hasil pengamatan di sekolah, guru matematika belum menggunakan modul sebagai sumber belajar. Hal ini dikarenakan minimnya guru matematika di sekolah. Sehingga harus membagi waktu mengajar dan sebagai wali kelas. Kesibukan tersebut menyebabkan guru tidak pernah membuat sumber belajar berupa modul. Selain itu, buku paket KTSP sebagai sumber belajar utama yang digunakan dalam kegiatan belajar mengajar. Senada dengan temuan (Sukiminiandari et al., 2015), sekitar $80 \%$ guru belum menggunakan bahan ajar berupa modul. Temuan lain menyatakan guru juga cenderung menggunakan buku paket dari penerbit sebagai satu-satunya sumber pembelajaran dan belum mengembangkan LKS secara optimal selain itu, tidak ada satupun guru yang mengembangkan dan menggunakan modul matematika dalam pembelajaran (Suryani, Suryani, \& Mukhtar, 2016).

Selanjutnya, Ketika siswa dihadapkan dengan Latihan soal yang diambil dari buku pegangan guru kurikulum 2013. Hasilnya semua siswa 
DOI: https://doi.org/10.24127/ajpm.v10i4.4250

memperoleh nilai di bawah KKM yaitu 65. Kemudian dilakukan tanya jawab terkait apa yang diketahui dan ditanyakan dari soal tersebut terlihat hanya beberapa siswa yang menjawab dengan benar.

Berdasarkan pemaparan di atas tujuan penelitian ini adalah menghasilkan modul pembelajaran matematika dengan pendekatan saintifik untuk meningkatkan kemampuan pemecahan masalah matematika siswa yang valid, praktis dan efektif. Selain itu, modul merupakan jenis perangkat pembelajaran yang bisa dikembangkan oleh guru sendiri sehingga dapat disesuaikan dengan karakteristik siswa.

\section{METODE PENELITIAN}

Tempat penelitian dilaksanakan di MIS Al-Hilaal Laimu Kecamatan Tehoru Kabupaten Maluku Tengah. Waktu penelitian dilaksanakan pada tanggal 20 April - 15 Mei tahun 2021. Subjek penelitian dilakukan pada siswa kelas V MIS Al-Hilaal Laimu Kecamatan Tehoru Kabupaten Maluku Tengah yang berjumlah sebelas siswa. Pada penelitian ini menggunakan metode penelitian dan pengembangan yang bertujuan untuk menghasilkan produk baru melalui proses pengembangan.

Rancangan model pengembangan dalam penelitian ini dengan menggunakan model pengembangan perangkat pembelajaran menurut Dick dan Cary yaitu model ADDIE yang merupakan singkatan dari analysis (analisis), design (desain), development (pengembangan), implementation and evaluation (implementasi dan evaluasi) (Mulyatiningsih, 2013).

Prosedur pengembangan dalam penelitian ini disesuaikan dengan prosedur penyusunan modul dan prosedur pengembangan desain model ADDIE. Penjelasan dari prosedur pengembangan dalam penelitian ini dapat dilihat pada Tabel 1.

Tabel 1. Prosedur pengembangan model ADDIE

\begin{tabular}{|c|c|}
\hline $\begin{array}{l}\text { Tahap } \\
\text { ADDIE }\end{array}$ & Kegiatan \\
\hline Analysis & $\begin{array}{l}\text { Tahap analisis, bertujuan untuk mengkaji masalah modul, yaitu mengenai } \\
\text { analisis kurikulum dan analisis karakteristik siswa, prosedur pengembangan } \\
\text { serta kelebihan dan kekurangan modul. Selanjutnya mengkaji standar isi untuk } \\
\text { materi bangun ruang dengan kompetensi dasarnya, mengkaji strategi masalah } \\
\text { dengan pendekatan saintifik dan terakhir mengkaji beberapa modul lain. Analisis } \\
\text { ini dilakukan untuk menentukan masalah dasar yang diperlukan dalam } \\
\text { pengembangan modul pembelajaran matematika. }\end{array}$ \\
\hline Design & $\begin{array}{l}\text { Tahap desain, bertujuan untuk membuat desain modul pembelajaran yang akan } \\
\text { dikembangkan. pada tahap ini membuat gambaran isi dari modul pembelajaran } \\
\text { yang akan dibuat antara lain yaitu merencanakan rancangan sampul modul dan } \\
\text { isi dari modul itu sendiri yang meliputi tujuan pembelajaran, uraian materi, } \\
\text { proses penilaian, dan Menyusun komponen kelengkapan modul. }\end{array}$ \\
\hline Develop & $\begin{array}{l}\text { Tahap pengembangan merupakan tahap memproduksi modul pembelajaran, } \\
\text { meliputi penyiapan materi untuk siswa dan pengajar sesuai dengan spesifikasi } \\
\text { produk yang dikembangkan. Pada tahap pengembangan dilakukan } \\
\text { penggabungan bahan seperti materi pembelajaran, gambar, pengetikan dengan } \\
\text { bantuan Microsoft word yang kesemuanya dikembangkan menjadi modul yang } \\
\text { utuh serta sesuai dengan materi dan tujuan yang akan disampaikan dalam } \\
\text { pembelajaran. }\end{array}$ \\
\hline
\end{tabular}


DOI: https://doi.org/10.24127/ajpm.v10i4.4250

\begin{tabular}{ll}
\hline \multicolumn{1}{c}{ Tahap } & \multicolumn{2}{c}{ Kegiatan } \\
ADDIE & \multicolumn{1}{c}{} \\
\hline Implemen & Tahap implementasi merupakan tahap dilaksanakannya penerapan modul \\
tation & pembelajaran matematika pada guru matematika dan siswa MIS Al-Hilaal \\
& $\begin{array}{l}\text { Laimu. Selama implementasi, rancangan model/ metode yang telah } \\
\text { dikembangkan diterapkan pada kondisi yang sebenarnya. }\end{array}$ \\
Evalua & $\begin{array}{l}\text { Tahap evaluasi bertujuan untuk melihat kevadilan, kepraktisan dan keefektifan } \\
\text { tion }\end{array}$ \\
& $\begin{array}{l}\text { modul pembelajaran matematika yang telah divalidasi oleh tim ahli, serta telah } \\
\text { diuji cobakan pada guru matematika dan siswa. }\end{array}$ \\
\hline
\end{tabular}

Metode pengumpulan data yang digunakan dalam penelitian ini adalah metode angket dan observasi. Metode angket dalam penelitian ini berupa angket validasi modul pembelajaran matematika dan angket respon siswa. Sedangkan observasi yang dilakukan merupakan observasi terstruktur, yaitu observasi yang telah dirancang secara sistematis, tentang apa yang akan diamati, kapan dan dimana tempatnya.

Instrumen pengumpulan data yang digunakan dalam penelitian ini diklasifikasikan menjadi tiga macam untuk memenuhi kriteria kevalidan, kepraktisan dan keefektifan yaitu; a) lembar validasi, digunakan untuk mengukur kevalidan modul pembelajaran matematika. Selanjutnya lembar validasi berupa angket yang akan diajukan kepada dosen ahli dan guru mata pelajaran matematika; b) angket respon siswa, digunakan untuk mengukur aspek kepraktisan. Angket ini bertujuan mendapatkan data mengenai pendapat siswa tentang proses pembelajaran yang dialami siswa di kelas; c) lembar observasi kegiatan pembelajaran, untuk mengukur aspek kepraktisan; d) tes kemampuan pemecahan masalah dilaksanakan diakhir pembelajaran dengan menggunakan post test untuk mengukur aspek keefektifan. Teknik analisis data dalam penelitian ini berupa analisis kevalidan, kepraktisan, dan keefektifan.

\section{HASIL DAN PEMBAHASAN}

Dalam mengembangkan modul terdapat empat tahapan yaitu: 1) analisis: 2) perancangan; 3) implementasi dan; 4) evaluasi. Berikut dipaparkan tahapan analisis dan perancangan terkait pengembangan modul matematika. Berikut ini hasil pengembangan modul matematika dengan pendekatan saintifik:

1. Tahap analysis (analisis)

a. Analisis kebutuhan

Pada tahap ini bertujuan untuk memunculkan masalah dasar yang dibutuhkan dalam pengembangan modul matematika. Ada beberapa hal yang harus diperhatikan dan menjadi dasar pertimbangan untuk menghasilkan modul matematika dengan pendekatan saintifik adalah kurikulum pada MIS Al-Hilaal Laimu.

b. Analisis karakteristik siswa

Pada tahap ini diketahui bagaimana karakteristik siswa dan pengetahuan awal siswa. Untuk mengetahui karakteristik siswa, dapat dilakukan wawancara dengan guru matematika siswa kelas V MIS AlHilaal Laimu.

\section{c. Analisis konsep}

Pada tahap ini telah diidentifikasi

dan Menyusun konsep dari materi bangun ruang pada mata pelajaran matematika kelas V MIS Al-Hilaal Laimu. 
DOI: https://doi.org/10.24127/ajpm.v10i4.4250

d. Analisis kurikulum

Pada tahap ini berguna untuk mengetahui kurikulum yang berlaku di sekolah, kompetensi dasar dan indikator pembelajaran. Selain itu, dapat diketahui materi pada pelajaran matematika yang dapat dijadikan sebagai modul pembelajaran. Sehingga pada tahap perancangan desain produk dan komponen pada modul matematika sesuai dengan kurikulum yang digunakan.

\section{Tahap design (perancangan)}

a. Merancang kerangka modul

Pada tahap ini bertujuan untuk merumuskan dan menetapkan indikator yang akan menjadi landasan untuk memilih materi yang ditampilkan dalam modul yang dikembangkan.

\section{b. Design (perancangan)}

Desain modul yang telah dirancang berupa cover, kata pengantar, daftar isi, kompetensi inti dan kompetensi dasar, petunjuk penggunaan modul dan tujuan pembelajaran. Selanjutnya ditunjukkan pada Gambar 1-5.

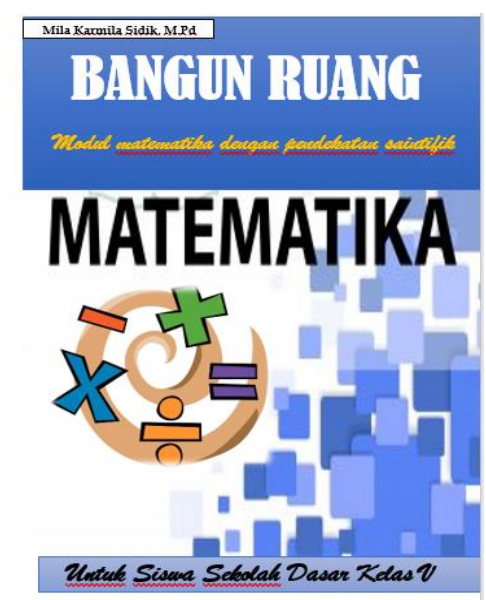

Gambar 1. Tampilan Depan

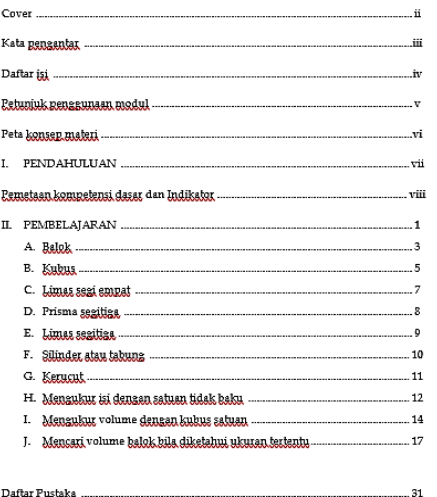

Gambar 2. Daftar isi

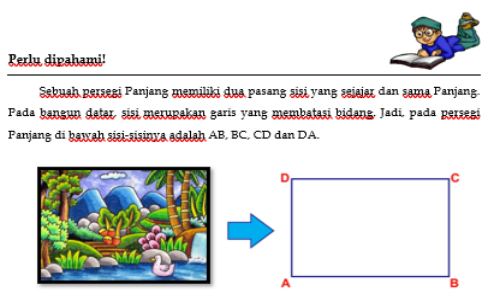

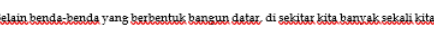

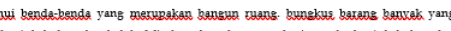

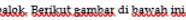

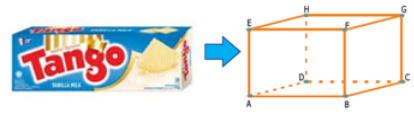

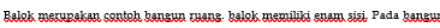

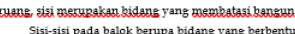

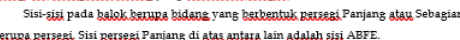

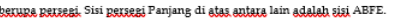

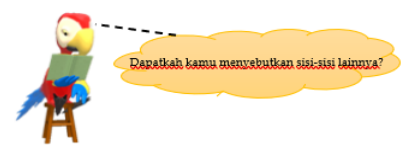

Gambar 3. Tampilan isi materi
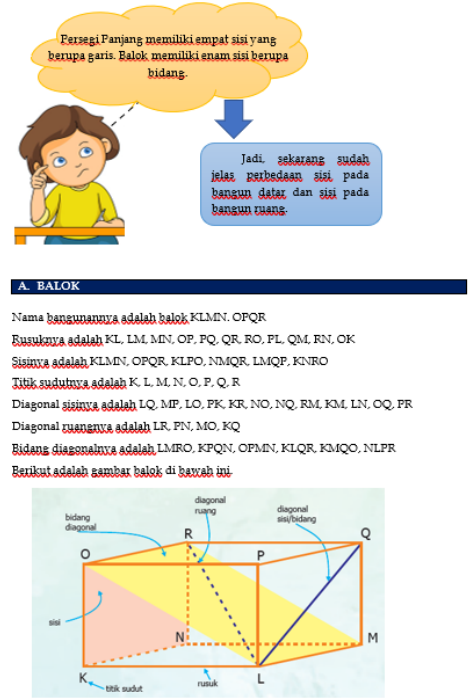

Gambar 4. Materi balok (1) 
DOI: https://doi.org/10.24127/ajpm.v10i4.4250

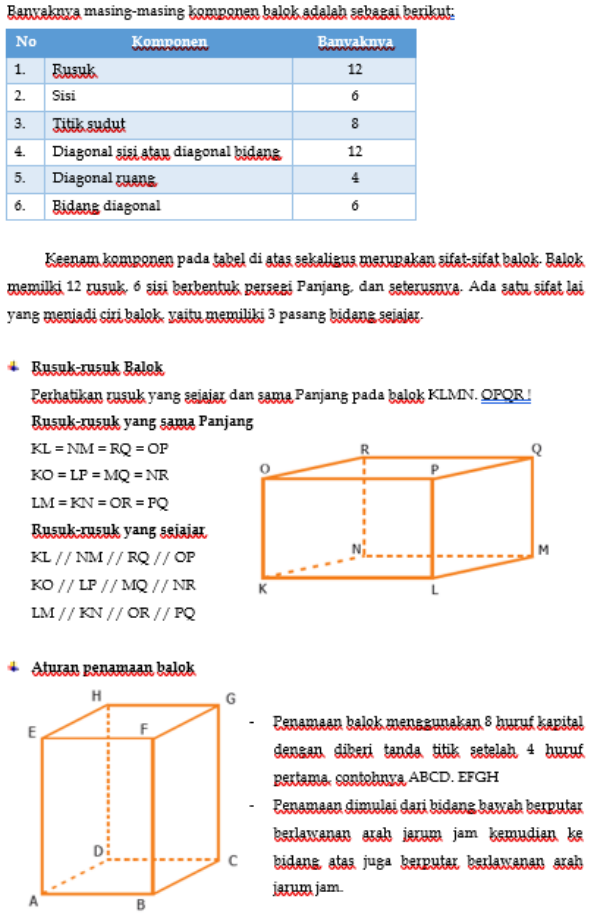

Gambar 4. Materi balok (2)

\section{Pengembangan (development)}

Pada tahap pengembangan meliputi beberapa aspek yaitu sebagai berikut:

a. Pembuatan produk

Pembuatan modul pembelajaran dimulai dari cover, kemudian bagian awal modul pembelajaran dijelaskan mengenai petunjuk belajar dengan menggunakan Bahasa yang mudah dipahami, kompetensi dasar yang ingin dicapai dan indikator pembelajaran, serta materi bangun ruang. Untuk evaluasi, diberikan soal latihan untuk melihat kemampuan siswa dalam memahami materi bangun ruang yang terdapat pada modul pembelajaran matematika. Setelah pembuatan modul selesai, maka proses percetakan modul pembelajaran matematika dilakukan.

\section{b. Analisis uji coba produk}

Uji coba produk dilakukan agar memperoleh masukan tentang produk yang dikembangkan. Hasil evaluasi uji coba produk digunakan untuk merevisi modul pembelajaran matematika yang telah dibuat.

Adapun proses uji coba yang dilakukan adalah sebagai berikut:

1) Analisis uji coba satu-satu

Uji coba produk dilakukan pada seorang guru matematika yang mengajar di kelas V MIS Al-Hilaal Laimu Kecamatan Tehoru. Guru diminta untuk mengamati dan menilai modul pembelajaran matematika dengan menggunakan angket.

Berdasarkan respon guru, diperoleh jumlah skor uji coba angket penilaian modul untuk guru yaitu 67 dengan presentasi 96\%. Skor ini termasuk dalam rentang 81-100 dengan kategori "sangat praktis".

2) Uji coba modul pembelajaran matematika

Setelah uji coba dari guru matematika, selanjutnya siswa kelas $\mathrm{V}$ MIS Al-Hilaal Laimu kecamatan Tehoru yang berjumlah 11 orang diberi angket penilaian siswa terhadap modul pembelajaran matematika.

Berdasarkan penilaian angket tersebut, diperoleh jumlah skor yaitu 39 dengan presentasi $70 \%$. Skor ini termasuk dalam kategori "praktis". Sehingga dari hasil analisis, modul pembelajaran matematika sudah layak untuk dilakukan penilaian uji coba di lapangan.

\section{3) Revisi produk}

Modul pembelajaran matematika berada pada kategori "sangat praktis" hal ini terlihat dari penskoran yang diberikan oleh guru mata pelajaran matematika kelas V MIS Al-Hilaal Laimu Kecamatan Tehoru. Tidak ada komentar atau saran dari penilaian oleh karena itu modul pembelajaran matematika tidak perlu di revisi lagi. 
DOI: https://doi.org/10.24127/ajpm.v10i4.4250

Hasil uji coba pada modul pembelajaran matematika pada siswa kelas V MIS Al-Hilaal Laimu Kecamatan Tehoru sebanyak 11 orang. Modul pembelajaran matematika berada pada kategori "praktis" sehingga modul pembelajaran matematika tidak perlu direvisi lagi.

\section{Implementasi (implementation)}

Tahap implementasi, modul pembelajaran matematika dengan pendekatan saintifik diimplementasikan di kelas V MIS Al-Hilaal Laimu Kecamatan Tehoru yang berjumlah 11 siswa. Kegiatan pembelajaran dilaksanakan selama 3 kali pertemuan.

Pada tahap implementasi dilakukan observasi untuk melihat keefektifan siswa dalam menggunakan modul pembelajaran matematika dengan pendekatan saintifik. Observasi dilakukan saat kegiatan pembelajaran berlangsung dan observasi dilaksanakan sebanyak tiga kali pertemuan.

Selanjutnya, soal post-test terdiri dari dua soal uraian. Uji coba soal posttest dilakukan pada siswa kelas V MIS Al-Hilaal Laimu Kecamatan Tehoru yang berjumlah 11 siswa. Dari soal tersebut akan dilihat efektifitas modul pembelajaran matematika.

Hasil analisis observasi aktifitas siswa menunjukkan rata-rata keseluruhan aspek yaitu 75 dengan kategori "efektif" artinya pembelajaran menggunakan modul, siswa menjadi aktif selama proses pembelajaran.

Hasil analisis tes kemampuan pemecahan matematika siswa (post-test) dapat dikatakan bermanfaat dan efektif jika kemampuan pemecahan masalah matematika siswa $\geq 65$. Dalam pelaksanaan post-test diikuti 11 siswa. Terlihat nilai hasil post-test kelas $\mathrm{V}$ MIS Al-Hilaal Laimu yang mendapatkan nilai tertinggi yaitu empat siswa dengan skala penilaian $80 \leq x \leq$ 100, siswa dengan nilai sedang yaitu tujuh siswa dengan skala penilaian $65 \leq x \leq 80$.

\section{Evaluasi (Evaluation)}

Tujuan evaluasi adalah untuk melihat kelayakan dari modul pembelajaran matematika dengan pendekatan saintifik yang telah dibuat. Disimpulkan dari ketiga indikator yaitu kevalidan, kepraktisan dan keefektifan modul pembelajaran matematika yang telah digunakan memiliki kelayakan baik.

Sumber belajar adalah segala sesuatu atau alat/media yang berpengaruh dalam kualitas pembelajaran (Sidik, 2020). Selain itu, sumber belajar adalah sumber pendukung untuk proses pembelajaran yang dipergunakan oleh guru dan siswa (Rosiyanti \& Muthmainnah, 2018). Salah satunya yaitu dengan memanfaatkan modul sebagai sumber belajar.

Menurut Ekawati, Anggoro, \& Komarudin (2019), modul merupakan bahan ajar cetak dalam pembelajaran mandiri dengan topik yang terintegrasi, hal ini dikarenakan modul berisi informasi yang dibutuhkan siswa untuk mencapai dan menilai pengetahuan dan kemampuan tertentu. Menurut Mutiyati \& Yuniarty (2020), modul pembelajaran yang dikembangkan dengan memiliki kriteria layak atau valid dapat digunakan sebagai sumber belajar dalam pembelajaran matematika

Hasil temuan menunjukkan kemampuan pemecahan masalah matematika siswa kelas V MIS AlHilaal Laimu Kecamatan Tehoru yang mengikuti post-test sebanyak 11 siswa tuntas. Sehingga persentase keefektifan modul adalah $100 \%$ dengan kriteria sangat baik, sehingga disimpulkan modul pembelajaran matematika yang telah dibuat sangat efektif. 
Berdasarkan temuan Suryani \& Mukhtar (2016), hasil penelitian menunjukkan perangkat pembelajaran dengan pendekatan saintifik telah valid, efektif, dan praktis dibuktikan dari hasil uji pengembangan: (1) modul matematika berbasis pendekatan saintifik memenuhi kriteria kevalidan berdasarkan para ahli, (2) memenuhi kriteria efektif digunakan berdasarkan hasil pengamatan pencapaian persentase waktu ideal, dan memenuhi hasil ketuntasan klasikal yaitu $85 \%$ dari subjek uji coba, dan dari hasil observasi kemampuan guru mengelola pembelajaran, serta (3) memenuhi kriteria praktis berdasakan angket respon guru dan siswa.

Selain itu, temuan Fatmawati (2019), hasil penelitian menunjukkan kelayakan bahan ajar matematika berbasis pendekatan saintifik mendapat nilai validasi yang sangat valid dan termasuk kategori sangat baik sehingga layak digunakan. Respon siswa akan kemenarikan bahan ajar matematika berbasis pendekatan saintifik adalah sangat positif. Kepraktisan bahan ajar berdasarkan respon siswa, dapat disimpulkan bahwa bahan ajar matematika berbasis pendekatan saintifik adalah sangat praktis digunakan oleh siswa.

Modul pembelajaran matematika yang valid, praktis dan efektif berdampak positif terhadap kemampuan siswa di kelas. selain itu, modul pembelajaran matematika merupakan sumber belajar yang dapat menyajikan materi dan soal latihan secara lengkap.

\section{KESIMPULAN DAN SARAN}

Berdasarkan penelitian dan pembahasan yang telah dipaparkan, pengembangan modul matematika telah divalidasi oleh ahli materi, desain dan bahasa, dengan memperoleh kriteria valid atau layak digunakan. Kepraktisan dinilai oleh guru matematika dan siswa kelas V MIS Al-Hilaal Laimu dengan memperoleh kriteria "sangat praktis" dan sudah layak digunakan. Keefektifan dilihat dari meningkatnya hasil kemampuan pemecahan masalah matematika siswa yang berada pada kategori sedang dan tinggi sehingga keefektifan modul pembelajaran matematika yang telah dibuat "sangat efektif". Disimpulkan ketiga indikator yaitu kevalidan, kepraktisan dan keefektifan pada modul pembelajaran matematika memiliki kelayakan baik dan dapat digunakan dalam pembelajaran.

Saran-saran yang disampaikan berdasarkan hasil penelitian yaitu kepada guru agar senantiasa menjalankan tanggung jawabnya bukan hanya mengajar dan membimbing, namun bertanggung jawab membuat sumber belajar yang kreatif dan inovatif, dan kepada peneliti lain untuk dapat mengkaji dan meneliti ulang masalah ini, sebab hasil penelitian ini masih jauh dari kata sempurna. Hal ini dikarenakan penelitian dilaksanakan pada saat pandemic covid 19 sehingga keterbatasan waktu dalam penelitian, namun demikian semoga hasil penelitian ini dapat dijadikan acuan untuk penelitian selanjutnya.

\section{DAFTAR PUSTAKA}

Ahmad, M., \& Asmaidah, S. (2017). Pengembangan Perangkat Pembelajaran Matematika Realistik Untuk Membelajarkan Kemampuan Pemecahan Masalah Matematika Siswa SMP. Jurnal "Mosharafa," 6(September), 373-384.

Anggoro, B. S. (2015). Pengembangan Modul Matematika Dengan Strategi Problem Solving untuk Mengukur Tingkat Kemampuan Berpikir Kreatif Matematis Siswa. Al-Jabar: 
DOI: https://doi.org/10.24127/ajpm.v10i4.4250

Jurnal Pendidikan Matematika, 6(2), 121-129. Retrieved from http://ejournal.radenintan.ac.id/inde x.php/al-jabar/article/view/25/436

Ekawati, T., Anggoro, B. S., \& Komarudin. (2019). Pengembangan Modul Pembelajaran Matematika Pada Materi Statistika Terintegrasi Nilai-Nilai Keislaman. AKSIOMA: Jurnal Program Studi Pendidikan Matematika, 8(1), 184-192. https://doi.org/10.24127/ajpm.v8i1. 1826

Fatmawati, B. A. (2019). Pengembangan Bahan Ajar Matematika Berbasis Saintifik. Tesis, pp. 1-85. Salatiga. Retrieved from http://journal.unj.ac.id/unj/index.ph p/psdpd/article/view/9935

Harahap, E. R., \& Surya, E. (2017). Kemampuan Pemecahan Masalah Matematis. Prosiding Seminar Nasional Penelitian, Pendidikan Dan Penerapan MIPA, 553-558.

Hidayati, A., \& Widodo, S. (2015). Proses Penalaran Matematis Siswa dalam Memecahkan Masalah Matematika pada Materi Pokok Dimensi Tiga Berdasarkan Kemampuan Siswa di SMA Negeri 5 Kediri. Jurnal Math Educator Nusantara, Vol 1(2), 1-13.

Laila, H. T., \& Darmawan, H. (2021). Hubungan Kemampuan Pemecahan Masalah Matematis dengan Kemampuan Komunikasi Matematik Siswa. Aksara: Jurnal Ilmu Pendidikan Non Formal, 07(02), 463-474.

Latifah, T., \& Afriansyah, E. A. (2021). Kesulitan dalam kemampuan pemecahan masalah matematis siswa pada materi statistika. Journal of Authentic Research on Mathematics Education (JARME), 3(2), 134-150.

Mulyatiningsih, E. (2013). Metode Penelitian Terapan Bidang pendidikan (Cetakan I; A.
Nuryanto, Ed.). Bandung: Alfabeta. Retrieved from http://www.albayan.ae

Mutiyati, \& Yuniarty. (2020). 19 Implementasi Pendidikan Pada Masa Covid Dalam Perspektif Sosiologi. Edification, 3(1). https://doi.org/https://doi.org/10.37 092/ej.v3i1.207

Rosiyanti, H., \& Muthmainnah, R. N. (2018). Penggunaan Gadget Sebagai Sumber Belajar Mempengaruhi Hasil Belajar Pada Mata Kuliah Matematika Dasar. FIBONACCI: Jurnal Pendidikan Matematika Dan Matematika, 4(1), 25. https://doi.org/10.24853/fbc.4.1.2536

Sidik, M. K. (2017). Analisis Proses Berpikir Induktif Siswa SMP Dalam Memecahkan Masalah Himpunan. Universitas Muhammadiyah Malang, Malang.

Sidik, M. K. (2020). School Library Utilization As a Source of Learning Mathematics In Madrasah Tsanawiyah Negeri 1 Wakatobi. SENDIKA, 6(2), 239-244.

Sukiminiandari, Y. P., Budi, A. S., \& Supriyati, Y. (2015). Pengembangan Modul Fisika dengan Pendekatan Saintifik. Prosiding Seminar Nasional Fisika (E-Journal) SNF2015, IV, 161-164.

Suryani, D. R., Suryani, E., \& Mukhtar. (2016). Pengembangan Modul Matematika Berbasis Pendekatan Pembelajaran Saintifik di SMP Negeri 8 Padangsidempuan. Paradikma, 9(3). 